INTERNATIONAL JOURNAL OF MULTidisciplinARY RESEARCH AND ANALYSis

ISSN(print): 2643-9840, ISSN(online): 2643-9875

Volume 05 Issue 01 January 2022

DOI: 10.47191/ijmra/v5-i1-28, Impact Factor: 6.072

Page No.- 225-235

\title{
Motivational Strategies of Teachers in Relation To Learners' Academic Performance
}

\author{
Analyn D. Pulana ${ }^{1}$, Rexomar D. Perez ${ }^{2}$ \\ 1,2Teacher II, Victorias National High School, Philippines
}

ABSTRACT: Motivating learners is one of the most critical and challenging parts of teaching. As such, they differ in how they motivate students and their motivational strategies. This quantitative inquiry determined the motivational strategies of teachers and students' academic performance according to age, civil status, teaching experience, highest educational attainment, and average monthly income. To answer the descriptive and inferential questions, a researcher-made questionnaire was utilized. It was revealed that the level of motivational strategies of teachers in the areas of (1) introduction of the lesson, (2) discussion of the lesson, and (3) assessment of lesson we're all on a high level. However, the results indicated that the respondents least prefer helping learners prepare for the discussion using a pre-formed questionnaire, informal classroom debates, and a strategy that allows learners to assess their peers and classmates' writing abilities and comprehension skills.

Consequently, the level of learners' academic performance was very satisfactory. Likewise, no significant differences in the level of teachers' motivational strategies in the first and second areas when grouped according to age, civil status, teaching experience, and highest educational attainment. Additionally, no significant difference showed when teachers were grouped according to average monthly income in the first and third areas. It can conclude that most teachers are proceeding directly to lesson discussion and skipping the introduction to maximize class hours. Also, teachers have different motivational strategy preferences in engaging their learners. Likewise, they have a different mindset in motivating the lesson. As such, different strategies will positively influence academic performance. It is recommended that teachers be regularly subjected to seminars and training in pedagogical and instructional methods and other classroom management skill training to improve teaching practices and to help improve students' academic performance.

KEYWORDS: Education, Motivational Strategies, Teachers and Learners, Academic Performance, Quantitative, Philippines

\section{INTRODUCTION}

Shaping the learning environment and motivating students to learn is the main task of the teacher (Hornstra et al., 2015). They can differ in motivating students to learn, and their motivational strategies may vary (Hornstra et al., 2015). Additionally, motivating learners is one of the most important and the most challenging parts of being a teacher. Some teachers are often confused about how to help learners meet the required academic goals and objectives because motivation must come from within. Since teachers have a significant influence in nurturing the minds and hearts of every individual, improving their motivational strategies will have a significant impact on learners' academic and behavioral success.

Teachers' motivation is considered a critical factor that influences their performance effectiveness. It catalyzes big or small-scale academic successes. With motivated teachers, the success rate for schools to achieve collective goals and objectives is way higher. Hence, motivation at work is essential because this ensures that every work is done right within a limited time frame, and the quality of work rendered is not compromised (Gichure, 2014). As such, the researcher encountered massive issues in addressing various learning needs of adolescent learners. It is then recognized the need to think outside of the box to provide a strong motivational force to keep the learners going. Hence, a quantitative inquiry was a medium to understand the shared motivational strength of teachers in keeping learners on the right track. It determined the critical learning factors affecting learners' academic performance.

\section{METHODS}

This study utilized the descriptive- correlational research design to determine teachers' motivational strategies to learners' academic performance of a secondary high school to observe and describe the behavior of a subject without influencing it in any 


\section{Motivational Strategies of Teachers in Relation To Learners' Academic Performance}

way using the quantitative information (Ward \& Cole, 2016). Hence, a total population of forty-nine teachers who are officially employed and teaching in a public secondary high school was utilized as respondents.

A two-part constructive survey questionnaire was administered to the 41 respondents. The first part was the demographic profile, including age, civil status, teaching experience, highest educational attainment, and average monthly income. Consequently, the second part consists of the 30-line items. The questions were categorized in three areas (introduction of the lesson, lesson discussion, and lesson assessment). The questions were referred to the Philippine Professional Standards for Teachers (PPST) to be conceptualized since it captures teacher quality requirements in the $\mathrm{K}$ to 12 basic education programs. It was then subjected to content validation of experts in the field. They provided scientific suggestions to develop an improved questionnaire that would heighten the level of validity of the instrument. Thus, the validity index utilized the criteria set forth by Carter Good and Douglas Scates with a mean score of 4.85 . Hence, it is valid. Moreover, a reliability test was then conducted (Santos, 2016) with the value of 0.962 interpreted as with a high degree of reliability.

The researcher administered the survey to raise questions or clarify issues, gather essential information and subject the data to statistical treatment. The frequency count and percentage for profiling are age, civil status, teaching experience, highest educational attainment, and average family monthly income. Additionally, the mean was used to determine the level of motivational strategies in the different areas and variables and students' academic performance. Consequently, the MannWhitney $U$ test determined the significant difference in teachers' motivational strategies when grouped and compared according to variables. Likewise, Spearman's rank-order correlation was used to determine the significant relationship between teachers' level of motivational strategies and students' academic performance.

\section{RESULTS AND DISCUSSION}

Table 1. Profile of the Respondents According of Age, Civil Status, Teaching Experience, Highest Educational Attainment and Average Monthly Income

\begin{tabular}{|l|l|l|l|}
\hline Variables & Category & Frequency & Percentage \\
\hline \multirow{2}{*}{ Age } & Younger (below 37 years old) & 22 & 53.7 \\
\cline { 2 - 4 } & Older (37 years old and above) & 19 & 46.3 \\
\hline \multirow{2}{*}{ Civil Status } & Single & 16 & 39.0 \\
\cline { 2 - 4 } & Married & 25 & 61.0 \\
\hline \multirow{3}{*}{ Teaching Experience } & Shorter (below 10 years) & 25 & 61.0 \\
\cline { 2 - 4 } & Longer (10 years and above) & 16 & 39.0 \\
\hline \multirow{3}{*}{ Highest Educational Attainment } & Bachelor & 27 & 65.9 \\
\cline { 2 - 4 } & Masters & 14 & 34.1 \\
\hline \multirow{3}{*}{ Average Monthly Income } & Lower (below 26,500) & 24 & 58.5 \\
\cline { 2 - 4 } & Higher (26,500 and above) & 17 & 41.5 \\
\cline { 2 - 4 } & Total & $\mathbf{4 1}$ & $\mathbf{1 0 0 . 0}$ \\
\hline
\end{tabular}

It shows the profile of the respondents according to age, civil status, teaching experience, highest educational attainment, and average monthly income.

Table 2. Level of Motivational Strategies of Teachers in the areas of Introduction of the Lesson, Discussion of Lesson and Assessment of the Lesson

\begin{tabular}{|l|l|l|}
\hline Area & Mean & Interpretation \\
\hline Introduction of the Lesson & 4.43 & High Level \\
\hline Discussion of the Lesson & 4.40 & High Level \\
\hline Assessment of the Lesson & 4.48 & High Level \\
\hline
\end{tabular}

Results showed that in the area, the lesson's introduction, the level of motivational strategies was high. According to Wilcox and Lawson (2018), if we are going to inspire and motivate all of our students truly, we should know them personally. Knowing their interests and hobbies, who they hang out with, their family situations, and what gets them excited. Each student will require different motivational strategies, and we have to know them to predict what strategies might work. Consequently, in the area (discussion of the lesson), the level of the motivational strategy was also high. As Haj-Broussard (2018) states, teachers' practice of enhancing student motivation in learning requires motivational strategies that provide instructional interventions applied by 


\section{Motivational Strategies of Teachers in Relation To Learners' Academic Performance}

the teacher to elicit and stimulate student motivation. They also proposed various motivational strategies to promote students' motivation in classroom learning. However, these strategies are not theoretically grounded. Likewise, the level of motivational strategy of teachers in the area of assessment of the lesson was also high. It means that most teachers recognize that motivating their learners is part of their job, though it is more important for some than for others. In specific educational contexts, learners may or may be expected to bring high initial levels of motivation. Hence, the teacher's focus is on maximizing the efficiency of the learning processes. At the other extreme, there are pedagogic contexts where learners are compelled to attend, and the teacher's main task seems to be persuaded to engage in learning tasks (Lamb \& Arisandy, 2020).

Table 3. Level of Motivational Strategies of in the areas (Introduction of the Lesson) and according to variables (Age, Civil Status, Teaching Experience, Highest Educational Attainment and Average Monthly Income)

\begin{tabular}{|c|l|l|}
\hline \multicolumn{2}{|c|}{ Variables/Area } & \multicolumn{2}{|c|}{ Introduction of the Lesson } \\
\cline { 2 - 3 } & Mean & Interpretation \\
\hline Age (Younger) & 4.36 & High Level \\
( Older) & 4.51 & Very High Level \\
\hline $\begin{array}{c}\text { Civil Status (Single) } \\
\text { (Married) }\end{array}$ & 4.36 & High Level \\
\hline $\begin{array}{c}\text { Teaching Experience } \\
\text { (Shorter) } \\
\text { (Longer) }\end{array}$ & 4.47 & High Level \\
\hline $\begin{array}{c}\text { Highest Educational Attainment } \\
\text { (Bachelor) } \\
\text { (Masters) }\end{array}$ & 4.40 & High Level \\
(Lower) & 4.48 & High Level \\
\hline $\begin{array}{c}\text { Average } \\
\text { (Honthly Income }\end{array}$ & 4.48 & High Level \\
(Higher) & 4.30 & High Level \\
\hline
\end{tabular}

The table reveals that the younger groups are least likely to provide positive feedback to learners. At the same time, the older respondents are less likely to help learners get engaged in discussions by providing pre-discussion questions. Teachers' positive feedback easily persuades the latter to be more motivated to join discussions. However, feedbacking could not be mandatory for teachers as it may take substantial time from their teaching load. Regarding the distribution of pre-discussion questions to help engage learners, there is no guarantee that learners' engagement is easy to achieve learners' engagement quickly. Learners can be given proper motivation in various practical ways because motivating students is one of the most significant teachers' challenges. It is true that as teachers, we have little, if any, control over external factors that influence our learners' behavior and engagement. We do play a vital role in shaping what occurs in our classroom. Our instructional choices can positively impact student motivation (BONGABONG-BAGUIO).

Additionally, research revealed that unmarried respondents are less likely to provide constructive or positive feedback to learners to help motivate them to learn new subjects. Positive feedbacking may be given to learners to acknowledge their exemplary works and good deeds. But married respondents are less likely to motivate learners by helping them with prediscussion questions. It is essential to provide learners with a heads-up on what is coming with new subject discussions because this will help prepare them better for the discussion. As such, an inspiring teacher can affect students profoundly by stimulating their interest in learning. It is equally valid that most students have encountered uninspiring teachers who performed poorly. But effective and ineffective teachers have no readily discernable personality differences. Some of the best teachers are affable, but many ineffective instructors can be personable and caring (BONGABONG-BAGUIO).

The above results show that the short-tenured respondents are less likely to give positive feedback to learners. It does not mean that the shorter-tenured teachers are less-motivating learners. Rather their option to engage learners into discussion may be through a different activity. And the more-tenured respondents indicated that they are less inclined to assist learners at the onset of new subject matter discussion by helping them with pre-set questions. Tenured teachers may have a different way of helping learners engage with classroom discussions. Styles may individually vary, according to individual teachers, although the result indicated that these low-scored line items were least preferred. Typically, some best teachers appear as stern taskmasters, but whose influence is enormous in motivating students to accomplish things they never thought possible. However, the finest teachers display enthusiasm and excitement for the subjects they teach. They are proficient in the technical competencies of teaching: instructional delivery, formative assessment, and classroom management (Lamb \& Arisandy, 2020). 


\section{Motivational Strategies of Teachers in Relation To Learners' Academic Performance}

Results also revealed that Bachelor's Degree Holder respondents see constructive criticism as the least motivation strategy in engaging learners in group or class discussions. In contrast, the Masters/Doctoral degree holders believed that selecting a format to aid learners in achieving the desired output in terms of being motivated is lesser than other possible activities (Balchin et al., 2019).

Accordingly, the lower-income group believed that providing positive criticism to challenge learners will always motivate learners. On the other hand, respondents belonging to higher income groups believed that setting discussion formats in the delivery of lesson content may not always be the best option to motivate the learners into actively participating in classroom discussions. It can be attributed to the unique differences of teachers in analyzing what's effective and what's not. Students' self-belief is essential, but teachers also have a significant role. Teachers can help give students the confidence to build on their skills. One way to do this is by promoting a growth mindset. It is the theory that they can develop ability and performance through fostering a positive environment. The opposite of a fixed mindset is a person's talents are already fixed from birth. Developing a growth mindset is essential because it positively encourages us to see new challenges. It involves praising effort rather than just focusing on outcomes (Balchin et al., 2019).

The study showed that the younger respondents are least likely to provide initial pair-off questions at the onset of the discussion. They also believed that there is a need for a deeper student-teacher discussion to help engage learners. Meanwhile, the older respondents believed that integrating ICT-based matters may not always engage learners in discussions. As it appeared, the younger and older respondents have a different outlook in defining motivational strategies to help engage learners.

The school and students' success in terms of learning progress lies in the awareness and leadership of the teacher in delivering the programs. The teacher then is expected to initiate techniques and strategies that create a meaningful and favorable atmosphere in which the educational process is successfully taking place (Ramos et al., 2021).

Table 4. Level of Motivational Strategies of in the areas (Discussion of the Lesson) and according to variables (Civil Status, Teaching Experience, Highest Educational Attainment and Average Monthly Income)

\begin{tabular}{|c|c|c|}
\hline \multirow[b]{2}{*}{ Variables/Area } & \multicolumn{2}{|c|}{ Discussion of the Lesson } \\
\hline & \multirow{3}{*}{$\begin{array}{l}\text { Mean } \\
4.42 \\
4.40\end{array}$} & \multirow{3}{*}{$\begin{array}{l}\text { Interpretation } \\
\text { High Level } \\
\text { High Level }\end{array}$} \\
\hline Age (Younger) & & \\
\hline (Older) & & \\
\hline Teaching Experience & & \\
\hline (Shorter) & 4.40 & High Level \\
\hline (Longer) & 4.42 & High Level \\
\hline Highest Educational Attainment & & \\
\hline (Bachelor) & 4.41 & High Level \\
\hline (Masters) & 4.39 & High Level \\
\hline Average Monthly Income & & \\
\hline (Lower) & 4.27 & High Level \\
\hline (Higher) & 4.60 & Very High Level \\
\hline
\end{tabular}

The table reveals that unmarried or single respondents are less likely to discuss new lessons with a question-and-answer activity. In contrast, those married respondents believed that having ICT matters involved in discussions is not an excellent, motivating strategy for learners. It is related to the idea that the classroom process begins with a lengthy lecture, and the question-andanswer portion comes at the end. Furthermore, it is also a fact that learners considered digital natives might not be interested in hearing their teacher with ICT matters while they already know it. Another teacher's responsibility is his role in improving meaningful instruction and learning. He should see what goes on in the classroom to find how students can learn effectively. Towards improving students' performance, he has to assist students in making plans about the choice of methods, materials, and evaluation procedures. Moreover, he has to relate well with students to communicate clear learning goals (Ramos et al., 2021).

The shorter tenured group, presumably composed of younger teachers, believed that starting with a pair of questions for learners to answer will not necessarily improve the percentage of learners' participation and engagement in classroom discussions. Less-tenured respondents are dominantly eager to kick off classes with a discussion and throw questions at the later part of the class. The longer-tenured respondents believed that it is not always wise to involve ICT matters in every class 


\section{Motivational Strategies of Teachers in Relation To Learners' Academic Performance}

discussion as longer-tenured respondents are mostly those who belong to the older group, which means that their competence in discussing ICT matters will be too taxing for them. Balacuit \& Inabangan (2019) believed that motivation is either intrinsic or extrinsic, a positive force that drives an individual to pursue achievement. It has been exhaustedly believed that students' motivation is relevant in attaining high academic performance. Meanwhile, students' motivation has a high positive significant correlation in their academic performance or achievement.

Also, the results showed that the Bachelors' Degree Group (lower) was less likely to discuss integrated ICT matters to motivate learners to get involved in discussions. At the same time, the Masters and the Doctorate group (higher) are less likely to initiate an informal classroom debate to motivate learners into getting involved in classroom discussions. These lowest mean scores do not indicate the teacher's low motivating abilities; instead, these show that teachers may have different motivating strategies. They played a significant role in the learners' cognitive development. Tongson \& Eslit (2018) explored the relations between teachers' teaching style and students' perceived self-efficacy, readiness for schoolwork, and their learning performance in mathematics. Results showed that authoritarian teachers expressed lower self-efficacy and readiness for schoolwork. Students taught by the permissive teacher achieved the lowest performance level. There were no significant performance differences between authoritarian teachers.

Likewise, the table revealed that the low-income group preferred not to have an informal debate about specific issues and topics in the classroom. In contrast, the higher income group preferred to use motivational strategies other than integrating ICT matters in class discussions. Since the respondents, regardless of their income level, have different strategies in motivating learners. The lowest scored line items do not indicate the respondents' weaknesses in motivating learners. Maintaining quality instruction is the goal of every school to meet the challenges and demands of globalization. However, education nowadays faces many challenges, specifically in language teaching. The risk of producing "instructional competent learners" who know the language but cannot use it communicatively is a persistent and existing problem that has challenged every competent language teacher.

Table 5. Level of Motivational Strategies of in the areas (Assessment of the Lesson) and according to variables (Age, Civil Status, Teaching Experience, Highest Educational Attainment and Average Monthly Income)

\begin{tabular}{|c|c|c|}
\hline \multirow[b]{2}{*}{ Variables/Area } & \multicolumn{2}{|c|}{ Assessment of the Lesson } \\
\hline & Mean & Interpretation \\
\hline $\begin{array}{ll}\text { Age } & \text { (Younger) } \\
& \text { ( Older) }\end{array}$ & $\begin{array}{l}4.43 \\
4.54\end{array}$ & $\begin{array}{l}\text { High Level } \\
\text { Very High Level }\end{array}$ \\
\hline $\begin{array}{l}\text { Civil Status (Single) } \\
\text { (Married) }\end{array}$ & $\begin{array}{l}4.47 \\
4.48\end{array}$ & $\begin{array}{l}\text { High Level } \\
\text { High Level }\end{array}$ \\
\hline $\begin{array}{c}\text { Teaching Experience } \\
\text { (Shorter) } \\
\text { (Longer) }\end{array}$ & $\begin{array}{l}4.46 \\
4.51\end{array}$ & $\begin{array}{l}\text { High Level } \\
\text { Very High Level }\end{array}$ \\
\hline $\begin{array}{l}\text { Highest Educational Attainment } \\
\text { (Bachelor) } \\
\text { (Masters) }\end{array}$ & $\begin{array}{l}4.45 \\
4.54\end{array}$ & $\begin{array}{l}\text { High Level } \\
\text { Very High Level }\end{array}$ \\
\hline $\begin{array}{l}\text { Average Monthly Income } \\
\text { (Lower) } \\
\text { (Higher) }\end{array}$ & $\begin{array}{l}4.31 \\
4.72\end{array}$ & $\begin{array}{l}\text { High Level } \\
\text { Very High Level }\end{array}$ \\
\hline
\end{tabular}

The result showed that the younger respondents are less likely to ask learners to give reflective statements about the subject matter and this could be due to the fact that younger teachers have a different way of motivating the learners. The Older group indicated that they are less likely to allow learners to assess each other's writing ability and reading comprehension level because learners may not be capable of doing so. As cited by Kazakova et al. (2020), teachers believe motivation is important to student learning. As such, methods they employ to address student motivation may prove ineffective. Foreign students have higher values and educational motives at the initial stages of education during their first two years of study.

Also, it indicates that the unmarried group are less likely to ask learners to provide post-discussion statements reflective of what was discussed as this may shy learners away instead of being motivated. Meanwhile, the married group believed that integrating ICT in discussion may not necessarily be an excellent motivating strategy to ensure that learners' assessment is high. This could be attributed to the fact that those married respondents are mostly older and their competence 


\section{Motivational Strategies of Teachers in Relation To Learners' Academic Performance}

in dealing with ICT related matters may not be that strong. In short, they would prefer a different strategy. According to Moore et al. (2017) there currently is an abundant knowledge-base to inform us that in school teachers play the critical role in student learning achievement. Research reveals that how teachers instruct and these interactions with students are the cornerstone around which to build effective schools.

Likewise, it was revealed that the less tenured respondents are less like to engage in letting learners provide reflective statements after the class discussion. This can be attributed to the fact that these less tenured respondents who were mostly younger have dynamic ideas on how to motivate learners. The tenure respondents on the other hand believed that allowing learning to assess each other's writing abilities and comprehension level may be out of hand. Young learners don't have the capabilities to assess comprehension level as this is way too technical for them. This means that both groups have a different idea on how to properly motivate learners into getting good assessment results. McWhorter et al. (2019), believes that skills enhancement is an important part of teaching and learning. The moment a teacher stops being a student, the teaching process becomes ineffective. Each time a lesson is taught, a formula is given or an experiment is performed, teacher has to learn along and live it a fresh. Teachers can recall those memories of their classrooms when they might have dozed off, not because the topics were boring or they were tired. It happened due to the absence of presentation skills in the teacher. The question is not about the knowledge, which is of course the assured possession with a teacher.

Consequently, the Bachelors' group (lower) do not adhere to the idea that asking learners to provide reflective sentences may help motivate them, they would instead opt for a different strategy. With regard to the Masters and Doctorate group (higher), they believed that allowing learners to assess each other's comprehension level would improve the latter's motivation level. The study of Shousha (2018), indicated that motivation is essential to language learning achievement and attainment. It is more important than good teaching, abilities or curriculum in learning a language and maintaining it. It helps students to overcome any undesirable learning conditions they face in learning the language. Motivating learners is a long- term development. To motivate learners, teachers use variety of motivational strategies. Motivated teachers are "enthusiastic, resourceful, creative and strict".

Additionally, it was revealed that the lower income group do not adhere to the idea of requiring learners to provide reflective statements that would expound their own grasp of the discussed subject matter, and instead, they would opt for a different strategy. Meanwhile, the higher income group believed that allowing learners to assess each other's ability to write or comprehend things may not be a good motivation strategy due to the fact that this requires technical skills and as such, only the teachers may be able to do so. Cheung (2018), conducted a study in Hungary and found that the teacher's motivation has significant bearings on students' motivational disposition and, more generally, on their learning achievement. They conducted a theoretically grounded, evidence-based research that investigated teachers' motivational practice on student motivation. The research, conducted in South Korea, indicated that teachers' motivational practice has a positive impact on exhibited English-asa-foreign-language student motivation in language classrooms.

Table 6. Level of Learners' Academic Performance

\begin{tabular}{|l|l|l|}
\hline Variable & Mean & Interpretation \\
\hline Learners' Academic Performance & 88.78 & Very Satisfactory \\
\hline
\end{tabular}

Although the overall learners' performance is very satisfactory, there is still more room to improve. It means that with a bit of motivational push, learners' academic performance may even move a bit higher. Positive education facilitates crucial learning outcomes. The emergence of this paradigm has led to empirical investigations which focused on positive psychological constructs that serve as antecedents of adaptive academic functioning. One notable psychological variable that has been linked to a wide range of academic outcomes was positive affect. Positive affect pertains to individuals' experience desirable emotional states at various points in time. Previous literature has revealed that positive effect plays an essential role in fostering student success. Positive effect has been linked to greater academic engagement, meaning in life, and intrinsic motivation. Positive affect was also weakly associated with academic achievement. Yet, the positive effect has not been substantially associated with academic ability in undergraduate students (Datu et al., 2017).

Table 7. Difference in the Level of Motivational Strategies of Teachers in the Area of Introduction of the Lesson according to Variables

\begin{tabular}{|l|l|l|l|l|l|l|}
\hline Variable & Category & Mean & Mann Whitney U test & $\boldsymbol{p}$-value & Sig level & Interpretation \\
\hline Age & Younger & 4.36 & 165.5 & 0.252 & 0.05 & Not Significant \\
\hline
\end{tabular}


Motivational Strategies of Teachers in Relation To Learners' Academic Performance

\begin{tabular}{|c|c|c|c|c|c|}
\hline & Older & 4.51 & & & \\
\hline \multirow{2}{*}{ Civil Status } & Single & 4.36 & \multirow{2}{*}{170.0} & \multirow{2}{*}{0.419} & \multirow{2}{*}{ Not Significant } \\
\hline & Married & 4.47 & & & \\
\hline \multirow{2}{*}{ Teaching Experience } & Shorter & 4.40 & \multirow{2}{*}{180.0} & \multirow{2}{*}{0.590} & \multirow{2}{*}{ Not Significan } \\
\hline & Longer & 4.48 & & & \\
\hline \multirow{2}{*}{$\begin{array}{ll}\text { Highest Educational } \\
\text { Attainment }\end{array}$} & Bachelor & 4.40 & \multirow{2}{*}{168.0} & \multirow{2}{*}{0.561} & \multirow{2}{*}{ Not Significant } \\
\hline & Masters & 4.48 & & & \\
\hline \multirow[t]{2}{*}{ Average Monthly Income } & Lower & 4.30 & \multirow[t]{2}{*}{128.5} & \multirow[t]{2}{*}{0.044} & \multirow[t]{2}{*}{ Significant } \\
\hline & Higher & 4.62 & & & \\
\hline
\end{tabular}

The result of the study implies that age, civil status, teaching experience, and highest educational attainment do not significantly affect teachers' motivational strategies in terms of the introduction of the lesson. The result of the study further verified that regardless of whether they are younger or older, single or married, tenured or not, the teachers believed that there are better strategies that could help motivate learners. And that shared belief is commonly agreed to by all groups within the variables above. The study of Alufohai \& Ibhafidon (2015) agrees with the results of this study. In his study on the influence of age, marital status, and gender on teachers' motivation, the results showed that these three variables have no significant impact on the level of teachers' motivation. Also, Uddin (2016) agrees with the result of this study stating that teachers' income levels may cause differing opinions on teachers' motivation. In his study on factors affecting teachers' motivation, the result showed that teachers who belong to the lower-income group are more frustrated and less motivated. In contrast, the opposite is true for the higher income group.

Table 8. Difference in the Level of Motivational Strategies of Teachers in the Area of Discussion of the Lesson according to Variables

\begin{tabular}{|c|c|c|c|c|c|c|}
\hline Variable & Category & Mean & Mann Whitney U test & $p$-value & Sig level & Interpretation \\
\hline \multirow{2}{*}{ Age } & Younger & 4.38 & \multirow{2}{*}{205.5} & \multirow{2}{*}{0.926} & \multirow{10}{*}{0.05} & Not \\
\hline & Older & 4.43 & & & & Significant \\
\hline \multirow{2}{*}{ Civil Status } & Single & 4.42 & \multirow{2}{*}{195.5} & \multirow{2}{*}{0.903} & & Not \\
\hline & Married & 4.40 & & & & Significant \\
\hline \multirow{2}{*}{$\begin{array}{l}\text { Teaching } \\
\text { Experience }\end{array}$} & Shorter & 4.40 & \multirow{2}{*}{197.0} & \multirow{2}{*}{0.935} & & Not \\
\hline & Longer & 4.42 & & & & Significant \\
\hline \multirow{2}{*}{$\begin{array}{l}\text { Highest } \\
\text { Educational } \\
\text { Attainment }\end{array}$} & Bachelor & 4.41 & \multirow{2}{*}{181.5} & \multirow{2}{*}{0.834} & & \\
\hline & Masters & 4.39 & & & & Significant \\
\hline \multirow{2}{*}{$\begin{array}{l}\text { Average Monthly } \\
\text { Income }\end{array}$} & Lower & 4.27 & \multirow{2}{*}{133.0} & \multirow{2}{*}{0.057} & & Not \\
\hline & Higher & 4.60 & & & & Significant \\
\hline
\end{tabular}

The study of Can (2015) on the factors affecting teachers' motivation contradicted the results of this study. In his study, the factor level is high, and age and educational status significantly affect motivational factors, yet, gender, marital status, and Income are not influential on motivational factors. Moreover, younger teachers and those holding a master's degree were more affected by motivational factors than the others.

Table 9. Difference in the Level of Motivational Strategies of Teachers in the Area of Assessment of the Lesson according to Variables

\begin{tabular}{|l|l|l|l|l|l|l|}
\hline Variable & Category & Mean & Mann Whitney U test & $\boldsymbol{p}$-value & Sig level & Interpretation \\
\hline Age & Younger & 4.43 & 189.5 & 0.607 & 0.05 & Not Significant \\
\hline
\end{tabular}


Motivational Strategies of Teachers in Relation To Learners' Academic Performance

\begin{tabular}{|c|c|c|c|c|c|}
\hline & Older & 4.54 & & & \\
\hline \multirow{2}{*}{ Civil Status } & Single & 4.47 & \multirow{2}{*}{196.5} & \multirow{2}{*}{0.925} & \multirow{2}{*}{ Not Significant } \\
\hline & Married & 4.48 & & & \\
\hline \multirow{2}{*}{ Teaching Experience } & Shorter & 4.46 & \multirow{2}{*}{190.5} & \multirow{2}{*}{0.798} & \multirow{2}{*}{ Not Significant } \\
\hline & Longer & 4.51 & & & \\
\hline \multirow{2}{*}{$\begin{array}{l}\text { Highest Educational } \\
\text { Attainment }\end{array}$} & Bachelor & 4.45 & \multirow{2}{*}{172.5} & \multirow{2}{*}{0.647} & \multirow{2}{*}{ Not Significant } \\
\hline & Masters & 4.54 & & & \\
\hline \multirow{2}{*}{$\begin{array}{ll}\text { Average } & \text { Monthly } \\
\text { Income } & \end{array}$} & Lower & 4.31 & \multirow{2}{*}{112.0} & \multirow{2}{*}{0.014} & \multirow{2}{*}{ Significant } \\
\hline & Higher & 4.72 & & & \\
\hline
\end{tabular}

The study of Mura \& Vlacseková (2018) agreed with the results of this study. The findings showed that compensation packages and financial incentives are important factors for employees in the competitive market environment of the higher education sector. The research has also explored various issues teachers face in public sector HEls related to the factors mentioned above. Likewise, the study of Nawaz (2015) agreed with the study's results on the effect of Income on teachers' motivation level. The regression coefficients between motivation and independent variables revealed that employees are motivated by unbiased appraisals, students' positive behavior, friendly environment, availability of learning resources, small class size, less distance from the school, selecting upper class as target market, and autonomy is given school teachers.

Table 10.Relationship Between the Level of Motivational Strategies of Teachers and the Level of Learners' Academic Performance

\begin{tabular}{|c|c|c|c|c|}
\hline Variables & rho & Sig Level & $p$-value & Interpretation \\
\hline Motivational Strategies & & & & \\
\hline $\begin{array}{ll}\text { Learners' } & \text { Academic } \\
\text { Performance } & \end{array}$ & 0.157 & 0.05 & 0.326 & Not Significant \\
\hline
\end{tabular}

It shows that learners are capable of performing or attaining high academic ratings regardless of the ability of teachers to motivate themselves or their learners. Ibok (2020) contradicts the result of this study that examined the influence of teacher motivation on students' performance in mathematics in Calabar Municipality of Cross River State. The results obtained from the analysis revealed the relationship between the conditions of service and students' academic performance in Biology, the relationship between regular promotion, regular payment of salary, and student's academic performance in Biology.

\section{SUMMARY OF FINDINGS}

There was a total of 41 teachers who served as respondents for this study. The results showed that in terms of age, majority of Forty-one teachers served as respondents for this study. The results showed that in terms of age, the majority of them belong to the younger age group. Most of them were married but had a shorter teaching experience. Bachelor's Degree holders dominate the total number of respondents, and the majority of them belong to a lower monthly income. Likewise, the level of teachers' motivational strategies in the areas of the lesson's introduction, discussion of lesson, and assessment of lesson we're all on a high level. However, the results indicated that in the area of introduction of the lesson, the respondents least prefer helping learners prepare for the discussion using a preformed questionnaire. In the lesson's discussion area, respondents least prefer informal classroom debates. In assessing lessons, the respondents indicated that they prefer the strategy that allows learners to assess their peers and classmates' writing abilities and comprehension skills.

Additionally, when grouped according to variables, the result of the study indicated a high to a very high level of motivational strategies. Furthermore, the result showed that younger, single respondents with lower educational attainment and lower-income bracket indicated that their least preferred strategy in introducing lessons is providing constructive criticism. Meanwhile, the older respondents, mainly married, with higher educational attainment and higher income bracket, indicated that their least preferred strategy is the questionnaire before lesson discussion.

The level of learners' academic performance showed that the mean percentage score of students was very satisfactory. Additionally, there were no significant differences in the level of teachers' motivational strategies in the introduction of the lesson and discussion of the lesson when grouped according to age, civil status, teaching experience, and highest educational attainment; except when grouped according to average monthly income in the area of introduction of lesson and assessment of 


\section{Motivational Strategies of Teachers in Relation To Learners' Academic Performance}

the lesson. Likewise, there was no significant relationship between teachers' level of motivational strategies and learners' academic performance.

\section{CONCLUSIONS}

The teachers' motivational strategies were all at a high level. Still, the finding showed in the introduction of a lesson. The respondents are not keen on motivating learners by assisting them with pre-formed questions being distributed at the onset of the lecture. It is concluded that most of the respondents are not giving proper heads-up to learners on what will be discussed. It also indicates that teachers mostly skip lesson introduction and proceed to discussion. Depending on learners' responses, this could be beneficial because this will help maximize class hours; questions are placed at the end of the discussions. The study's findings showed that teachers are least likely to allow learners to have a friendly and informal classroom debate in the discussion of lessons. Most teachers have a different preference for their motivational strategy in engaging learners. Classroom debates primarily result in learners' behavior turning unruly inside the class. There are several strategies to enhance learners' engagement during subject discussion. In the area of assessment of lessons, the result of the study showed that respondents are least likely to allow their learners to assess each other's writing abilities and comprehension levels. As such, learners may not have the technical skills to assess their peers' writing ability or comprehension level. It is too technical for them, and there are other ways of motivating learners apart from this.

When grouped and compared according to the variables above, the study's finding revealed that in the area of introduction of the lesson, teachers have other means of motivating learners to study but not in assisting them with prediscussion questions about the subject matter. In the area of discussion of the lesson, the results showed that classroom debate is not their preferred motivational strategy, and lastly, in the area of assessment of the lesson, the finding of the study revealed that they are less likely to allow learners to assess their peers writing abilities and reading comprehension level. It can conclude based on these results that most of the teachers have a different mindset in providing learners with proper motivation. But to put things into proper perspective, some teachers may advocate the mentioned less-preferred strategies. Still, the majority of the respondents have a different take on this. Asking them to provide pre-discussion questions may not encourage them to participate as some may not have studied the lesson in advance. Also, informal classroom debates may only give the dominant and loud learners opportunities to silence the weaker ones, and besides, this may invite unruly behaviors. In the area assessment of lessons, the teachers are correct in refusing to allow learners to assess their peer's writing and reading comprehension skills because these require higher technical skills, which only the teachers could use.

The learners' Academic Performance was above-average, which means there is still plenty of room for motivational strategies to influence academic results positively. Excellence is not too far away. Also, the opinion of teachers in their level of motivational strategies differs according to income level. As shown in the result, teachers who belong to the lower-income bracket appeared to have a lower opinion of their strategy. At the same time, the higher income respondents were more confident that they were giving the right strategy. Lower-income respondents may have similar circumstances with most learners, and they too understand what it takes to be motivated from a socially disadvantaged standpoint.

Lastly, learners are unaffected by their teachers' motivational strategies. It shows that many of the respondents have an independent mindset regarding how they perform in school as learners. This kind of independence among learners can be attributed to their affinity to digital platforms where they can freely access bodies of knowledge without mainly waiting for their teachers.

\section{RECOMMENDATIONS}

It is recommended that grade level coordinators and subject teachers have uniformity of the primary motivational strategy employed by teachers. It can be planned during a Grade Level Meeting and must be documented. The strategy must be agreed upon by all teachers but without restriction. The teacher may opt to use additional strategies if the situation requires. Suggested motivational strategies during the lesson's introduction may include setting expectations. The subject teacher herself can do it before delivering each subject content. It allows Learners to make suggestions on what activity to perform to keep them engaged. Subject teachers can do it at least once a month to break the ice and involve learners' planning. Also, it would be nice to give learners a heads-up that they can be creative as much as they want during the class. It comes with strict teacher supervision to ensure that the objective of such activity is achieved. It can be done twice a week or at least four times a month to ensure that learners are given genuine freedom to be productive and many others.

Also, as part of the yearly INSET schedule, the school head must include training on how to use effective pedagogical and instructional methods like role-playing. It can be done with the teacher's guidance and may be used at least once a month to improve learners' absorption of the lesson. Use of differentiated instructions whenever needed. Not everyone in the class can 


\section{Motivational Strategies of Teachers in Relation To Learners' Academic Performance}

cope. The teacher must keenly observe learners' performance to determine who and when to use differentiated instruction. Another activity is group competition within the class. Dividing the class into groups and the subject teacher shall act as the moderator. Groups shall be given tasks, and the output must be graded to teach learners the importance of the so-called "Responsibility."Also, it would be helpful to allow learners to suggest discussion topics and how they want the class to proceed. Perhaps they want to sit in a circular-arranged chair with the teacher at the center or suggest preparing visuals (per group) on the topic to be discussed. And many others. The primary purpose of making learners feel empowered is to keep them engaged. The School Head must take the lead in identifying other effective motivational strategies that will share with all teachers.

Likewise, subject teachers should employ other strategies to encourage and engage learners in getting good assessment results. Activities may include feedbacking with positive scripting on assessment results. It will be done every after the assessment. Allow students to exchange papers after assessments; this can be done with the supervision of teachers at least twice a month to make them feel empowered.

Lastly, teachers are recommended to do some teaching strategies to keep learners motivated. (1) Begin the day with a success-oriented activity that is likely to be enjoyable for students. (2) Make the first experience with the subject matter as positive as possible. (3) Provide active instruction. (4) Keep lessons interesting. Use humor, examples, analogies, stories, and questions to facilitate the active participation of learners in your lectures and demonstrations. (5) Arrange learning activities that encourage students to move freely around the room while completing a task. (6) Set aside time each day for this to occur. It promotes self-exploration of the room and its resources while allowing the students to feel more independent. Hence, a good teacher can inspire hope, ignite the imagination and instil a love for learning.

\section{REFERENCES}

1) Alufohai, P. J., \& Ibhafidon, H. E. (2015). Influence of teachers' age, marital status and gender on students' academic achievement. Asian Journal of Educational Research, 3(4).

2) Balacuit, C. \& Inabangan, J. (2019). Influence of motivation towards the academic performance in games and sports among BSEd MAPEH interns in SDSSU-main Campus. International Journal of Physical Education, Sports and Health. Vol.6, No. 3.

3) Balchin, N., Booth, D., \& te Velde, D. W. (2019). How economic transformation happens at the sector level: evidence from Africa and Asia. ODI Report.

4) BONGABONG-BAGUIO, J. O. Y. Outcomes-Based Education: Teachers' Attitude and Implementation.

5) Can, S. (2015). Factors motivating teachers working at elementary and secondary schools. Procedia-Social and Behavioral Sciences, 174, 3087-3093.

6) Cheung, Y. L. (2018). The effects of writing instructors' motivational strategies on student motivation. Australian Journal of Teacher Education (Online), 43(3), 55-73.

7) Datu, J. A. D., Yuen, M., \& Chen, G. (2017). Development and validation of the Triarchic Model of Grit Scale (TMGS): Evidence from Filipino undergraduate students. Personality and Individual Differences, 114, 198-205.

8) Gichure, C. N. (2014). Factors influencing employee motivation and its impact on employee performance: A case of AMREF Health Africa in Kenya. Project report submitted to Chandaria School of business, United States International University, Africa. Summer.

9) Haj-Broussard, M. (2018). Ensuring High-Quality Dual Language Immersion Education: Louisiana's Certified Foreign Language Immersion Program Rubric. Research Issues in Contemporary Education, 3(1), 51-56.

10) Hornstra, L., Mansfield, C., van der Veen, I. et al. Motivational teacher strategies: the role of beliefs and contextual factors. Learning Environ Res 18, 363-392 (2015). https://doi.org/10.1007/s10984-015-9189-y

11) Ibok, E. (2020). The Effect of Teacher Motivation on Students' Performance in Biology in Calabar Municipality. Available at SSRN 3530543.

12) Kazakova, E., Kruchek, M., Moshkina, E., Sergeeva, O., \& Tikhomirova, E. (2020, November). ACTIVE LEARNING FOR KEEPING STUDENTS ENGAGED. In Proceedings of ICERI2020 Conference (Vol. 9, p. 10th).

13) Lamb, M., \& Arisandy, F. E. (2020). The impact of online use of English on motivation to learn. Computer Assisted Language Learning, 33(1-2), 85-108.

14) McWhorter, J. W., Raber, M., Sharma, S. V., Moore, L. S., \& Hoelscher, D. M. (2019). The nourish program: An innovative model for cooking, gardening, and clinical care skill enhancement for dietetics students. Journal of the Academy of Nutrition and Dietetics, 119(2), 202-203.

15) Moore, A. B., MacGregor, C., \& Cornelius-White, J. (2017). School personnel-student racial congruence and the achievement gap. Journal for Multicultural Education. 


\section{Motivational Strategies of Teachers in Relation To Learners' Academic Performance}

16) Mura, L., \& Vlacseková, D. (2018). Motivation of public employees: case study of Slovak teaching and professional staff. Administratie si Management Public, (31), 67-80.

17) Nawaz, S. (2015). Growth effects of institutions: A disaggregated analysis. Economic Modelling, 45, $118-126$.

18) Németh, B., Józwiak-Hagymásy, J., Kovács, G., Kovács, A., Demjén, T., Huber, M. B., ... \& Vokó, Z. (2018). Cost-effectiveness of possible future smoking cessation strategies in Hungary: results from the EQUIPTMOD. Addiction, 113, 76-86.

19) Rojo-Ramos, J., Manzano-Redondo, F., Barrios-Fernandez, S., Garcia-Gordillo, M. A., \& Adsuar, J. C. (2021). A descriptive study of specialist and non-specialist teachers' preparation towards educational inclusion. International Journal of Environmental Research and Public Health, 18(14), 7428.

20) Santos, J. L., Oliveira, D. C., de Hastreiter, A., Silva, G. B. D., \& Beltran, J. S. (2016). i in. 2016. Building an empiricallybased framework to value multiple publicgoods of agriculture at broad supranational scales, 56-70.

21) Shousha, A. I. (2018). Motivational strategies and student motivation in an EFL Saudi context. International Journal of English Language Education, 6(1), 20-44.

22) Tongson, M. B., \& Eslit, E. R. (2018). Teaching Styles and Language Performance: Towards a Development of an English Language Program. Online Submission.

23) Uddin, G. A., Alam, K., \& Gow, J. (2016). Population age structure and savings rate impacts on economic growth: Evidence from Australia. Economic Analysis and Policy, 52, 23-33.

24) Ward, W., \& Cole, R. (2016). Developing conversational multimedia tutorial dialogs. Educational Technology, 106, 901918.

25) Wilcox, K. C., \& Lawson, H. A. (2018). Teachers' agency, efficacy, engagement, and emotional resilience during policy innovation implementation. Journal of Educational Change, 19(2), 181-204. 